\title{
The impact of the oil and gas industry on TENORM of the desert sands in Ma'rib, central
} Yemen

\author{
Mohsen M.M. Ali ${ }^{1,2}$, Zhigang Li ${ }^{1,3}$, Hongtao Zhao ${ }^{1,3^{*}}$, Abdullah Rawashdeh ${ }^{1,4}$, Ibrahim Alfasatleh \\ ${ }^{1,4}$ Omar Alqudah ${ }^{4}$, Waleed Alquraishi ${ }^{2,5}$, Ahmed Al-Osta ${ }^{2,6}$ \\ ${ }^{\prime}$ Collage of Nuclear Science and Technology, Harbin Engineering University, Harbin \\ 150001, China. \\ ${ }^{2}$ National Atomic Energy Commission-Yemen (NATEC), Sana'a, Yemen. \\ ${ }^{3}$ Institute of Technical Physics, Heilongjiang Academy of Sciences, Harbin, 150086, China. \\ ${ }^{4}$ Jordan Atomic Energy Commission, Amman, Jordan \\ ${ }^{5}$ Hunan Key Laboratory for Super Microstructure and Ultrafast Process, School of Physics and \\ Electronics, Central South University, Changsha, Hunan, 410083, PR China \\ ${ }^{6}$ Physics Department, Faculty of Applied Science, Thamar University, Thamar, Yemen. \\ *Corresponding author: zhaohongtao1976@163.com.
}

\begin{abstract}
A measurement of technologically enhanced natural occurring radioactivity materials (TENORM) in sand samples in the petroleum-producing communities of Ma'rib Province Yemen was carried out. The HPGe detector was utilized to perform the measurements. The samples were collected from 35 sites. All samples were placed in a properly cleaned container and sealed for 28 days to attain a state of secular radioactive equilibrium before analysis. The radioactivity concentrations for nuclides ${ }^{40} \mathrm{~K},{ }^{232} \mathrm{Th},{ }^{226} \mathrm{Ra}$, and ${ }^{238} \mathrm{U}$ ranged between 430.716 654.666, 4.347 - 43.935, 4.824 - 27.936, and 1.083 - $15.437 \mathrm{~Bq} \mathrm{~kg}^{-1}$ respectively, with averages $560.583,20.676,14.556$ and $9.072 \mathrm{~Bq} \mathrm{~kg}^{-1}$ respectively. The results did not show any radiation risks.
\end{abstract}

Keywords: Desert sand; dose rate; gamma-ray spectrometry; Ma'rib - Yemen; natural radioactivity; oil and gas industry; TENORM.

\section{Introduction}

The natural sources of radioactive contamination are the remaining naturally occurring radioactive materials (NORM) in the Earth's crust rocks, such as those resulting from the dissolution of the element uranium and thorium, those caused by solar radiation, cosmic rays, and those caused by water and food. These radioactive elements may be enhanced by technological and human activities (Ali et al., 2019; Alrefae \& Nageswaran, 2017; Alrefae et al., 2018a; Demir et al., 2018). These materials are often reinforced through technological industries and various human activities. In these cases, they are called technologically enhanced naturally occurring radioactive materials
(TENORM). (Ali et al., 2020; Ali et al., 2019). Radioactive contamination is defined as the increasing amount of natural radiation following human use of natural and artificial radioactive materials. The discovery of atomic energy was accompanied by various radioactive materials left by nuclear experiments and reactors on Earth.

In recent years, the spread of these radioactive materials in the atmosphere has increased significantly. It has become a risk to public health, especially with the invention of the atomic bomb (Hassan et al., 2019; Ali et al., 2020; Alrefae, 2012). Although the radiation sources are multiple and diverse, most of the radiation is first transmitted through the 
atmosphere and then later passed through a series of other transitions, so radioactive contamination is considered a form of atmospheric pollution. While the pollution of the environment by toxic gases, solid and liquid waste, micro-organisms, etc., has become commonplace, where its causes are due to long periods (Attallah et al., 2018; Hilal et al., 2018; Alrefae et al., 2018b). Humanity has entered a new stage of immediate danger, threatened with annihilation after discovering radioactivity of uranium, radium, and other radioactive elements, which is one of the most severe environmental pollutants. The impacts of these pollutants have increased since the second half of the twentieth century because of scientific, technical, and industrial development in those nuclear and radiological energies, which become widely used in many fields (Fares, 2017; Argyrios et al., 2014). For example, many countries use nuclear power to generate electricity, and the total electricity generated by nuclear reactors recently reached about $15 \%$ of the electricity consumed globally (Argyrios et al., 2014). The present century is considered the century of the atom and radiation because it contains a significant degree of human exposure to radiation in medicine, industry, and others. Radioactive contamination, or so-called nuclear contamination, is one of the most dangerous types of environmental pollution. For example, if the sources of air pollution are stopped, within a few days, the air is back to normal. Sea and ocean waters can also dispose of their organic and inorganic pollutants a few years after their sources have disappeared (Argyrios et al., 2014). Radioactive contamination has several sources, which can be initially divided into two main parts: natural sources, which are represented in the residual elements in the rocks of the crust, such as those caused by the disintegration of the elements of uranium and thorium or those caused by solar radiation or cosmic rays or those caused by water and food. Industrial (Human) sources, where there are many industrial sources of radioactive contamination between nuclear power plants, nuclear research reactors, nuclear explosions, weapons, and factories that use ionizing radiation in their various activities. In addition, radioactivity resulting from the extraction of fossil fuels and minerals, also radioactivity caused by electrical appliances and uses medical and others (Majeed et al., 2014; Okeyode \& Oluseye, 2010; AlKhayat \& AlMaliki, 2020). The oil and gas industry is one of the industries that contain radioactive materials. Therefore, radioactivity from the oil and gas industry has been studied in many regions around the world. This study aims to investigate the possibility of radioactive contamination of the oil and gas industry on TENORM, i.e., ${ }^{40} \mathrm{~K},{ }^{232} \mathrm{Th},{ }^{226} \mathrm{Ra},{ }^{238} \mathrm{U}$ in Ma'rib province by conducting a direct analysis of the sand samples taken.

\section{Materials and methods}

\subsection{Study Area}

Province of Ma'rib in central of Yemen in the northeastern part of the capital Sana'a, located between latitude $\left(15^{\circ} 23^{\prime} 40.73^{\prime \prime}, 16^{\circ}\right.$ $\left.7^{\prime} 29.55^{\prime} \mathrm{N}\right)$ and longitude $\left(45^{\circ} 10^{\prime} 32.28^{\prime \prime}\right.$, $\left.44^{\circ} 46^{\prime} 33.83^{\prime \prime} \mathrm{E}\right)$ at an altitude of 944 metersabove sea level.

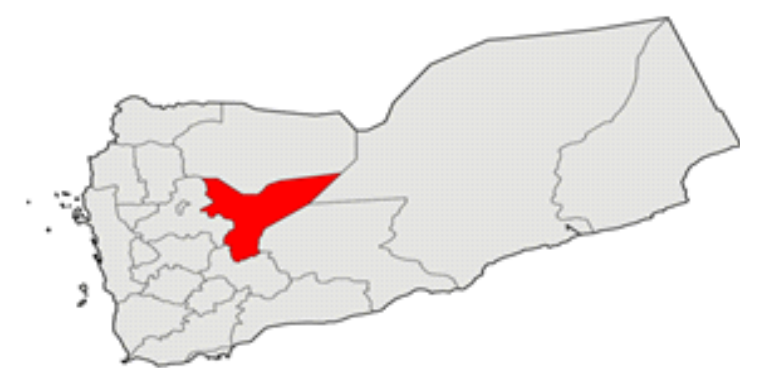

Fig. 1. Map of the study area.

There are less rainfall and crops with some minerals in its territory in the desert area, and the most important of which are granite, rock salt, gypsum, marble, and talc. The province of Ma'rib is the first of the Yemeni governorates where oil was discovered and began production in 1986. Most of the production and processing facilities of oil and gas are located in Ma'rib Province. (Our Yemen website management, 2015; National Information Center, 2006). 
Table 1. Location coordinates values.

\begin{tabular}{|c|c|c|c|}
\hline \multirow{2}{*}{ Sample } & \multirow{2}{*}{$\begin{array}{l}\text { Region } \\
\text { Name }\end{array}$} & \multicolumn{2}{|c|}{ Position } \\
\hline & & Longitude $\left({ }^{\circ} \mathrm{E}\right)$ & Latitude $\left({ }^{\circ} \mathrm{N}\right)$ \\
\hline $\mathrm{SO}_{1}$ & Almazarie & $45^{\circ} 47^{\prime} 23.74^{\prime \prime}$ & $15^{\circ} 33^{\prime} 32.45^{\prime \prime}$ \\
\hline $\mathrm{SO}_{2}$ & Kara & $45^{\circ} 48^{\prime} 58.56^{\prime \prime}$ & $15^{\circ} 31^{\prime} 36.46^{\prime \prime}$ \\
\hline $\mathrm{SO}_{3}$ & Al jamil & $45^{\circ} 46^{\prime} 2.25^{\prime \prime}$ & $15^{\circ} 32^{\prime} 22.40^{\prime \prime}$ \\
\hline $\mathrm{SO}_{4}$ & Aljathua & $45^{\circ} 41^{\prime} 13.47^{\prime \prime}$ & $15^{\circ} 32^{\prime} 45.41^{\prime \prime}$ \\
\hline $\mathrm{SO}_{5}$ & Alhani & $45^{\circ} 44^{\prime} 45.85^{\prime \prime}$ & $15^{\circ} 35^{\prime} 42.01^{\prime \prime}$ \\
\hline $\mathrm{SO}_{6}$ & Alhazma & $45^{\circ} 33^{\prime} 3.41^{\prime \prime}$ & $15^{\circ} 33^{\prime} 31.91^{\prime \prime}$ \\
\hline $\mathrm{SO}_{7}$ & Alrubue & $45^{\circ} 49^{\prime} 19.14^{\prime \prime}$ & $15^{\circ} 35^{\prime} 41.79^{\prime \prime}$ \\
\hline $\mathrm{SO}_{8}$ & Alramsa & $45^{\circ} 43^{\prime} 57.47^{\prime \prime}$ & $15^{\circ} 30^{\prime} 8.68^{\prime \prime}$ \\
\hline $\mathrm{SO}_{9}$ & Alearaqa & $45^{\circ} 35^{\prime} 27.57^{\prime \prime}$ & $15^{\circ} 30^{\prime} 28.25^{\prime \prime}$ \\
\hline $\mathrm{SO}_{10}$ & Alghawia & $45^{\circ} 30^{\prime} 31.14^{\prime \prime}$ & $15^{\circ} 30^{\prime} 46.97^{\prime \prime}$ \\
\hline $\mathrm{SO}_{11}$ & Alghajla & $45^{\circ} 39^{\prime} 8.27^{\prime \prime}$ & $15^{\circ} 27^{\prime} 18.24^{\prime \prime}$ \\
\hline $\mathrm{SO}_{12}$ & Sulua & $45^{\circ} 45^{\prime} 16.15^{\prime \prime}$ & $15^{\circ} 27^{\prime} 10.47^{\prime \prime}$ \\
\hline $\mathrm{SO}_{13}$ & Almumlah & $45^{\circ} 56^{\prime} 27.38^{\prime \prime}$ & $15^{\circ} 37^{\prime} 14.14^{\prime \prime}$ \\
\hline $\mathrm{SO}_{14}$ & Al shabwan & $46^{\circ} 0^{\prime} 15.73^{\prime \prime}$ & $15^{\circ} 39^{\prime} 41.10^{\prime \prime}$ \\
\hline $\mathrm{SO}_{15}$ & Althaman & $45^{\circ} 59^{\prime} 8.61^{\prime \prime}$ & $15^{\circ} 36^{\prime} 45.72^{\prime \prime}$ \\
\hline $\mathrm{SO}_{16}$ & Alkhushea & $46^{\circ} 1^{\prime} 55.71^{\prime \prime}$ & $15^{\circ} 37^{\prime} 21.73^{\prime \prime}$ \\
\hline $\mathrm{SO}_{17}$ & Alshaykh & $45^{\circ} 58^{\prime} 46.52^{\prime \prime}$ & $15^{\circ} 33^{\prime} 17.33^{\prime \prime}$ \\
\hline $\mathrm{SO}_{18}$ & Alshamar & $45^{\circ} 58^{\prime} 1.37^{\prime \prime}$ & $15^{\circ} 36^{\prime} 20.28^{\prime \prime}$ \\
\hline $\mathrm{SO}_{19}$ & Aljudean & $45^{\circ} 52^{\prime 2} 26.39^{\prime \prime}$ & $15^{\circ} 35^{\prime} 2.77^{\prime \prime}$ \\
\hline $\mathrm{SO}_{20}$ & Alrashid & $45^{\circ} 50^{\prime} 11.39^{\prime \prime}$ & $15^{\circ} 40^{\prime} 11.06^{\prime \prime}$ \\
\hline $\mathrm{SO}_{21}$ & Al misheal & $45^{\circ} 57 ' 28.71^{\prime \prime}$ & $15^{\circ} 27^{\prime} 2.41^{\prime \prime}$ \\
\hline $\mathrm{SN}_{1}$ & Jawalnasim & $46^{\circ} 32^{\prime} 39.29^{\prime \prime}$ & $16^{\circ} 0^{\prime} 26.08^{\prime \prime}$ \\
\hline $\mathrm{SN}_{2}$ & Alhusuwn & $46^{\circ} 18^{\prime} 35.01^{\prime \prime}$ & $15^{\circ} 58^{\prime} 1.31^{\prime \prime}$ \\
\hline $\mathrm{SN}_{3}$ & Alghajla & $46^{\circ} 25^{\prime} 1.88^{\prime \prime}$ & $15^{\circ} 50^{\prime} 32.40^{\prime \prime}$ \\
\hline $\mathrm{SN}_{4}$ & $\mathrm{Al}$ jalal & $46^{\circ} 4^{\prime} 38.83^{\prime \prime}$ & $15^{\circ} 52^{\prime} 56.42^{\prime \prime}$ \\
\hline $\mathrm{SN}_{3}$ & Al fajayh & $46^{\circ} 13^{\prime} 6.36^{\prime \prime}$ & $15^{\circ} 43^{\prime} 28.38^{\prime \prime}$ \\
\hline $\mathrm{SN}_{6}$ & $\mathrm{Al}$ jabir & $45^{\circ} 40^{\prime} 52.39^{\prime \prime}$ & $15^{\circ} 44^{\prime} 51.41^{\prime \prime}$ \\
\hline $\mathrm{SN}_{7}$ & Alhuma & $45^{\circ} 272.06^{\prime \prime}$ & $15^{\circ} 37^{\prime} 46.31^{\prime \prime}$ \\
\hline $\mathrm{SN}_{8}$ & Fyfil & $45^{\circ} 31^{\prime} 55.25^{\prime \prime}$ & $15^{\circ} 23^{\prime} 18.87^{\prime \prime}$ \\
\hline $\mathrm{SN}_{9}$ & Al misheal & $45^{\circ} 40^{\prime} 54.69^{\prime \prime}$ & $15^{\circ} 21^{\prime} 48.72^{\prime \prime}$ \\
\hline $\mathrm{SN}_{10}$ & Althania & $45^{\circ} 33^{\prime} 51.04^{\prime \prime}$ & $15^{\circ} 16^{\prime} 16.37^{\prime \prime}$ \\
\hline $\mathrm{SN}_{11}$ & Al qazea & $45^{\circ} 43^{\prime} 51.18^{\prime \prime}$ & $15^{\circ} 15^{\prime} 4.23^{\prime \prime}$ \\
\hline $\mathrm{SN}_{12}$ & Alhaway & $45^{\circ} 52^{\prime} 38.20^{\prime \prime}$ & $15^{\circ} 22^{\prime} 53.78^{\prime \prime}$ \\
\hline $\mathrm{SN}_{13}$ & Altahil & $45^{\circ} 53^{\prime} 29.61^{\prime \prime}$ & $15^{\circ} 45^{\prime} 7.70^{\prime \prime}$ \\
\hline $\mathrm{SN}_{14}$ & Al munif & $46^{\circ} 14^{\prime} 14.33^{\prime \prime}$ & $15^{\circ} 37^{\prime} 38.31^{\prime \prime}$ \\
\hline
\end{tabular}




\subsection{Collection and preparation samples}

Samples of sand were collected from thirtyfive sites in the Ma'rib desert, where a sand sample was taken from each site, as shown in Figure 1 and Table 1. Twenty-one samples were collected from in and around the fields and facilities of the oil and gas industry. These samples were labeled as type SO. For comparison, fourteen other samples were taken as controls from societies (sites) with no history of oil exploitation. These samples were labeled as type SN but with geographic and geological characteristics similar to oil and gas societies. The samples were collected during 2018. The samples were collected in a manner consistent with the achievement of the study objectives. Sand samples were taken directly from natural exposures from surface pits at a depth of 20-50 cm from the outer surface. All parts greater than 2 $\mathrm{mm}$ in diameter were excluded, and the initial sample weight ranged from $1-2 \mathrm{~kg}$, then dried, ground, and sieved. All samples were placed in clean plastic containers. Radioisotopes for sand samples were determined by taking a volume of $65 \mathrm{~mL}$ from each sample, weighing and placing them in the geometry of solid samples (Petri Dish). The Petri dishes were sealed tightly. All samples were ready to be measured and left in the laboratory for one month to ensure the secular equilibrium of radium isotopes and their short-lived decay products.

\section{3 Gamma-ray spectroscopy system}

The measurements were made by gammaray spectroscopy (Canberra) high-purity germanium detector (HPGe). All samples were counted for $20 \mathrm{hrs}$ to decrease the statistical uncertainty. The background radiation spectrum was used to determine the minimum detectable activity. The detector has a relative efficiency of $35 \%$, a resolution of $1.85 \mathrm{keV}$, for $1332 \mathrm{keV}$ gamma energy of ${ }^{60} \mathrm{Co}$. The detector is surrounded by a shield made of $10 \mathrm{~cm}$ thickness leads to reduce the background radiation level of the system, as well as padded from the inside with copper plates of $1 \mathrm{~mm}$ thickness to reduce the X-ray emitted by the interaction of cosmic radiation with the lead. The "Genie 2000 Gamma Analysis Software package" was used to analyze the spectral data. The detector's output is connected to the PC. The detector was calibrated using a standard sample containing several radioactive nuclides ${ }^{214} \mathrm{Am}$, ${ }^{60} \mathrm{Co},{ }^{88} \mathrm{Y},{ }^{137} \mathrm{Cs},{ }^{85} \mathrm{Sr},{ }^{203} \mathrm{Hg},{ }^{113} \mathrm{Sn},{ }^{139} \mathrm{Ce},{ }^{57} \mathrm{Co}$, and ${ }^{109} \mathrm{Cd}$. The absolute efficiency is obtained from using the efficiency curve for the standard source through equation 1 (Özmen et al., 2014; Ehsanpour et al., 2014):

$$
\begin{gathered}
\mathrm{Eff}(\mathrm{E})=\mathrm{a}+\mathrm{b}(\ln E)+\mathrm{C}(\ln E)^{2}+ \\
\mathrm{d}(\ln E)^{3}+\mathrm{e}(\ln E)^{4}+\mathrm{f}(\ln E)^{5}
\end{gathered}
$$

Where Eff (E) is the efficiency value, a, b, c, d, e, and $f$ are the optimal parameters determined by the synthesis algorithm. The efficiency values used to calculate the radioactivity concentration of TENORM.

\section{4 Measurement of TENORM}

The background intensity was obtained in the same conditions before and after measuring the samples for 64,800 seconds, using an empty Petri cup. The samples were measured at a record time of 64,800 seconds. After that, the background count mean was subtracted from the spectrum of the sample. The radioactivity concentrations of ${ }^{40} \mathrm{~K}$ were calculated directly by its gamma spectra, as shown in Table 2 . Radioactivity concentrations of ${ }^{232} \mathrm{Th},{ }^{226} \mathrm{Ra}$, and ${ }^{238}$ U were determined from their daughters' products. So to determine the radioactivity concentration of the ${ }^{232} \mathrm{Th}$ nuclide, daughter nuclide ${ }^{228} \mathrm{Ac}$ was used, while ${ }^{214} \mathrm{~Pb}$ and ${ }^{214} \mathrm{Bi}$ nuclides were chosen for the ${ }^{226} \mathrm{Ra}$, whereas daughter ${ }^{234} \mathrm{Th}$ was used for the ${ }^{238} \mathrm{U}$ nuclide as shown in Table 2 (Fares, 2017; Özmen et al., 2014; Lavi et al., 2004; Jallad, 2013). They were also calculated using the well-known equation 2 (Majeed et al., 2014; Okeyode \& Oluseye, 2010; Alrefae et al., 2018b):

$$
A=\frac{N_{\text {net }}}{\varepsilon \cdot I_{\gamma} m \cdot t} \quad\left[\mathrm{~Bq} \cdot \mathrm{kg}^{-1}\right]
$$


Table 2. The gamma-ray and its radioisotopes used to calculate the radioactivity concentrations of TENORM in sand samples.

\begin{tabular}{||ccc|}
\hline \hline Nuclide & Gamma-ray energy (keV) & Radioisotope \\
${ }^{40} \mathrm{~K}$ & 1460.83 & ${ }^{40} \mathrm{~K}$ \\
${ }^{232} \mathrm{Th}$ & $338.40,911.20$ & ${ }^{228} \mathrm{Ac}$ \\
& ${ }^{214} \mathrm{Bi}$ \\
${ }^{226} \mathrm{Ra}$ & $609.32,1120.28$ and 1764.91 & ${ }^{214} \mathrm{~Pb}$ \\
${ }^{238} \mathrm{U}$ & 295.21 and 351.93 & ${ }^{234} \mathrm{Th}$ \\
\hline
\end{tabular}

Where is the radioactivity concentrations, is the net area under photo-peak, is the detector's efficiency, is the transition probability of the emitted gamma-ray, is the sample weight (in $\mathrm{kg}$ ), is the time for spectrum collected (in a sec). The TENORM ${ }^{40} \mathrm{~K},{ }^{232} \mathrm{Th},{ }^{226} \mathrm{Ra}$, and ${ }^{238} \mathrm{U}$ concentrations were calculated and summarized in Table 3.

\section{5 Statistics}

The IBM SPSS-25 computer program was used to perform all the statistical assessments. Because the data set was non-parametric, the iterative distribution of the data sets was tested against the normal or logarithmic normal distribution by the KolmogorovSmirnov test (K-S) at the significance level $(\mathrm{p}>0.05)$. Statistical significance differences were calculated between samples taken from oil and non-oil societies using the MannWhitney test $(\mathrm{M}-\mathrm{W})$ at the significance level $(p>0.05)$. The average with the standard error, variance, standard deviation, minimum, maximum, range, skewness (degree of symmetry degradation), and kurtosis factor (peak degree) parameters was counted. The statistical data are summarized in Table 5.

\section{6 Radiographic maps}

Radiographic maps were created graphically using Google Earth, TCX 2.5 Converter, Server 9, and Excel software systems. The coordinates were read from GPS. The digital height model for the study area was created by digitizing contour lines from standard topographic maps. Radiological maps were made for TENORM, i.e., ${ }^{40} \mathrm{~K},{ }^{232} \mathrm{Th},{ }^{226} \mathrm{Ra}$, ${ }^{238} \mathrm{U}$, as in Figures 2, 3, 4, and 5.

\section{Results and Discussion}

Table 3 shows the TENORM concentrations in the sand at a depth of $20-50 \mathrm{~cm}$ using equation 2 and compared with the permitted global averages (UNSCEAR, 2000).

The range of radioactivity for ${ }^{40} \mathrm{~K}$ was between $430.72-654.67 \mathrm{~Bq} \mathrm{~kg}^{-1}$, and the average was $560.58 \mathrm{~Bq} \mathrm{~kg}^{-1}$. This is due to the cosmic rays as all samples were taken from Earth's surface (Bou-Rabee, 1997; Pillay et al., 2010). ${ }^{40} \mathrm{~K}$ contamination can arise from the continuous depletion of the Earth's crust containing natural radioactive material (Bou-Rabee, 1997; Baggoura et al., 1998). The activity concentrations of ${ }^{232} \mathrm{Th}$ ranged between $4.35-43.94 \mathrm{~Bq} \mathrm{~kg}^{-1}$, with an average of $20.68 \mathrm{~Bq} \mathrm{~kg} 1$. All radioactivity concentrations were less than the global average. The ${ }^{232} \mathrm{Th}$ generates the ${ }^{228} \mathrm{Ra}$, which in turn gives the ${ }^{228} \mathrm{Ac}$. Actinium is in a state of secular equilibrium with the parent. It is known that its presence at elevated levels in the environment poses a long-term health risk due to the toxicity of known radioactive materials. This radioisotope is also used as an indicator of high presence corresponding to ${ }^{228}$ Ra. (Sparks, 2003; Manahan, 2017; Harrison, 1992; Fifield and Haines, 2000). The activity concentrations of ${ }^{226} \mathrm{Ra}$ and ${ }^{238} \mathrm{U}$ 
Table 3. TENORM ${ }^{40} \mathrm{~K},{ }^{232} \mathrm{Th},{ }^{226} \mathrm{Ra}$ and ${ }^{238} \mathrm{U}$ Concentrations in $\mathrm{Bq} \mathrm{kg}^{-1}$ of sand samples from 35 desert spots in the Ma'rib region of Yemen.

\begin{tabular}{|c|c|c|c|c|}
\hline Sample & $\overline{{ }^{40} \mathrm{~K}}$ & ${ }^{232} \mathrm{Th}$ & ${ }^{226} \mathrm{Ra}$ & ${ }^{2338} \mathrm{U}$ \\
\hline $\mathrm{SO}_{1}$ & $595.77 \pm 13.36$ & $43.94 \pm 9.48$ & $11.63 \pm 1.46$ & $7.76 \pm 1.14$ \\
\hline $\mathrm{SO}_{2}$ & $612.50 \pm 17.48$ & $25.12 \pm 7.61$ & $14.51 \pm 1.76$ & $8.05 \pm 1.11$ \\
\hline $\mathrm{SO}_{3}$ & $563.81 \pm 15.84$ & $7.46 \pm 1.29$ & $18.23 \pm 2.17$ & $12.28 \pm 1.78$ \\
\hline $\mathrm{SO}_{4}$ & $475.27 \pm 10.71$ & $30.70 \pm 3.12$ & $27.45 \pm 3.22$ & $10.75 \pm 1.29$ \\
\hline $\mathrm{SO}_{5}$ & $521.69 \pm 24.49$ & $30.30 \pm 1.88$ & $17.08 \pm 1.49$ & $9.95 \pm 1.36$ \\
\hline $\mathrm{SO}_{6}$ & $654.67 \pm 20.43$ & $9.16 \pm 1.66$ & $14.27 \pm 2.32$ & $7.55 \pm 1.40$ \\
\hline $\mathrm{SO}_{7}$ & $591.11 \pm 1.29$ & $30.32 \pm 1.26$ & $26.40 \pm 2.29$ & $11.13 \pm 1.43$ \\
\hline $\mathrm{SO}_{8}$ & $576.45 \pm 25.46$ & $8.65 \pm 1.66$ & $27.94 \pm 2.02$ & $11.34 \pm 1.24$ \\
\hline $\mathrm{SO}_{9}$ & $495.68 \pm 18.07$ & $38.84 \pm 9.33$ & $14.75 \pm 1.84$ & $8.98 \pm 1.39$ \\
\hline $\mathrm{SO}_{10}$ & $430.72 \pm 14.67$ & $21.59 \pm 3.16$ & $6.18 \pm 1.90$ & $6.86 \pm 1.25$ \\
\hline $\mathrm{SO}_{11}$ & $558.56 \pm 17.74$ & $22.66 \pm 3.37$ & $12.37 \pm 1.73$ & $7.07 \pm 1.23$ \\
\hline $\mathrm{SO}_{12}$ & $598.88 \pm 25.79$ & $9.57 \pm 1.32$ & $12.90 \pm 1.47$ & $6.97 \pm 1.02$ \\
\hline $\mathrm{SO}_{13}$ & $586.87 \pm 17.85$ & $4.35 \pm 6.23$ & $4.82 \pm 1.545$ & $7.00 \pm 1.16$ \\
\hline $\mathrm{SO}_{14}$ & $588.93 \pm 23.26$ & $9.27 \pm 1.54$ & $10.50 \pm 2.25$ & $7.90 \pm 1.35$ \\
\hline $\mathrm{SO}_{15}$ & $563.56 \pm 17.76$ & $38.58 \pm 9.35$ & $13.65 \pm 2.15$ & $8.37 \pm 1.12$ \\
\hline $\mathrm{SO}_{16}$ & $586.22 \pm 21.67$ & $8.74 \pm 1.14$ & $15.23 \pm 1.86$ & $9.00 \pm 1.32$ \\
\hline $\mathrm{SO}_{17}$ & $591.50 \pm 15.37$ & $34.31 \pm 1.44$ & $14.77 \pm 2.82$ & $7.40 \pm 1.24$ \\
\hline $\mathrm{SO}_{18}$ & $576.43 \pm 16.72$ & $26.70 \pm 1.62$ & $16.51 \pm 2.92$ & $14.22 \pm 1.34$ \\
\hline $\mathrm{SO}_{19}$ & $612.58 \pm 21.50$ & $27.72 \pm 1.63$ & $22.23 \pm 2.15$ & $12.31 \pm 1.33$ \\
\hline $\mathrm{SO}_{20}$ & $558.20 \pm 19.38$ & $27.88 \pm 1.38$ & $21.25 \pm 2.31$ & $13.20 \pm 1.30$ \\
\hline $\mathrm{SO}_{21}$ & $520.80 \pm 25.39$ & $28.20 \pm 1.35$ & $21.69 \pm 1.70$ & $15.44 \pm 1.39$ \\
\hline $\mathrm{SN}_{1}$ & $596.97 \pm 29.56$ & $22.98 \pm 1.22$ & $13.72 \pm 2.07$ & $10.56 \pm 1.13$ \\
\hline $\mathrm{SN}_{2}$ & $530.63 \pm 24.75$ & $26.84 \pm 5.59$ & $7.67 \pm 1.85$ & $6.37 \pm 1.14$ \\
\hline $\mathrm{SN}_{3}$ & $561.68 \pm 27.48$ & $24.56 \pm 6.21$ & $11.80 \pm 1.93$ & $9.39 \pm 1.06$ \\
\hline $\mathrm{SN}_{4}$ & $472.32 \pm 23.70$ & $19.13 \pm 1.63$ & $10.97 \pm 2.79$ & $11.43 \pm 1.77$ \\
\hline $\mathrm{SN}_{3}$ & $488.87 \pm 29.53$ & $13.95 \pm 1.18$ & $17.90 \pm 2.82$ & $14.45 \pm 1.85$ \\
\hline $\mathrm{SN}_{6}$ & $586.22 \pm 26.82$ & $8.74 \pm 1.14$ & $13.83 \pm 1.67$ & $8.89 \pm 1.20$ \\
\hline $\mathrm{SN}_{7}$ & $557.94 \pm 22.38$ & $8.63 \pm 1.46$ & $13.14 \pm 1.68$ & $10.66 \pm 1.89$ \\
\hline $\mathrm{SN}_{8}$ & $572.19 \pm 28.56$ & $9.38 \pm 1.25$ & $15.77 \pm 2.09$ & $9.65 \pm 1.16$ \\
\hline $\mathrm{SN}_{9}$ & $556.67 \pm 18.47$ & $17.34 \pm 2.12$ & $8.74 \pm 1.13$ & $8.35 \pm 1.16$ \\
\hline $\mathrm{SN}_{10}$ & $470.08 \pm 12.89$ & $12.94 \pm 2.28$ & $6.88 \pm 1.03$ & $3.90 \pm 1.13$ \\
\hline $\mathrm{SN}_{11}$ & $567.45 \pm 16.42$ & $21.24 \pm 9.76$ & $16.25 \pm 1.78$ & $1.08 \pm 1.33$ \\
\hline $\mathrm{SN}_{12}$ & $609.69 \pm 13.75$ & $34.64 \pm 9.16$ & $10.61 \pm 2.18$ & $6.64 \pm 1.20$ \\
\hline $\mathrm{SN}_{13}$ & $569.24 \pm 23.89$ & $12.90 \pm 4.57$ & $12.90 \pm 4.57$ & $8.04 \pm 1.17$ \\
\hline $\mathrm{SN}_{14}$ & $620.32 \pm 25.82$ & $6.37 \pm 4.66$ & $4.94 \pm 1.69$ & $4.56 \pm 1.14$ \\
\hline Min & 430.72 & 4.35 & 4.82 & 1.08 \\
\hline $\operatorname{Max}$ & 654.67 & 43.94 & 27.94 & 15.44 \\
\hline Ave. & 560.58 & 20.68 & 14.56 & 9.07 \\
\hline a & 420 & 45 & 33 & 35 \\
\hline \multicolumn{5}{|c|}{ "Worldwide average value (UNSCEAR, 2000). (UNSCEAR, 2000) } \\
\hline
\end{tabular}

ranged between $4.82-27.94$ and 1.08 $-5.44 \mathrm{~Bq} \mathrm{~kg}{ }^{-1}$, respectively, with averages of 14.56 and $9.07 \mathrm{~Bq} \mathrm{~kg}^{-1}$, respectively. All radioactivity concentrations were lower than the world averages. The source of radium stems from the potential adsorption of rock materials and radioactive degradation from minerals because the oil is pumped from thousands of feetunderground. The TENORM concentrations of sand samples were compared with results obtained by other researchers in different areas of oil and 
Table 4. Comparison of TENORM ${ }^{40} \mathrm{~K},{ }^{232} \mathrm{Th}$, and ${ }^{226} \mathrm{Ra}$ concentrations of sand samples with different areas of oil and gas societies around the world.

\begin{tabular}{|c|c|c|c|c|c|}
\hline Country & Rang & ${ }^{40} \mathbf{K}$ & ${ }^{232} \mathrm{Th}$ & ${ }^{226} \mathrm{Ra}$ & Ref. \\
\hline \multirow{2}{*}{ Yemen } & Min & 430.72 & $(4.35$ & 4.82 & \multirow[b]{2}{*}{ [this study] } \\
\hline & Max & 654.67 & 43.94 & 27.94 & \\
\hline \multirow{2}{*}{ Egypt } & Min & 145.85 & 4.56 & 4.29 & \multirow{2}{*}{ (Fares, 2017) } \\
\hline & Max & 441.15 & 18.65 & 18.52 & \\
\hline \multirow{2}{*}{ Turkey } & Min & 19.0 & 1.8 & 4.0 & \multirow{2}{*}{$\begin{array}{c}\text { (Özmen et al., } \\
\text { 2014) }\end{array}$} \\
\hline & Max & 590.3 & 27.9 & 21.5 & \\
\hline Saudi & Min & 285.3 & 15.8 & 16.2 & \multirow{2}{*}{ (Alaamer, 2012) } \\
\hline Arabia & Max & 533.2 & 36.7 & 30.6 & \\
\hline \multirow{2}{*}{ China } & Min & 635.8 & 27.0 & 10.2 & (Xinwei and \\
\hline & Max & 1126.7 & 48.8 & 38.3 & Xiaolan, 2006) \\
\hline \multirow{2}{*}{ Sudan } & Min & 16.6 & 14.60 & 13.89 & \multirow{2}{*}{$\begin{array}{c}\text { (Abu-baker et al., } \\
2016 \text { ) }\end{array}$} \\
\hline & Max & 196.28 & 346.62 & 280.74 & \\
\hline \multirow[t]{2}{*}{ Sri Lanka } & Min & 0.338 & 0.030 & 0.012 & \multirow{2}{*}{$\begin{array}{c}\text { (Gamage et al., } \\
\text { 2018) }\end{array}$} \\
\hline & Max & 0.514 & 0.040 & 0.0145 & \\
\hline \multirow{2}{*}{ Norway } & Min & - & $<0.1$ & $<0.1$ & \multirow{2}{*}{ (Strand, 2004) } \\
\hline & $\operatorname{Max}$ & - & 13 & 22 & \\
\hline \multirow{2}{*}{ Kuwait } & Min & 43 & 3.2 & 3.8 & \multirow{2}{*}{$\begin{array}{c}\text { (Hassan et al., } \\
\text { 2019) }\end{array}$} \\
\hline & Max & 183 & 5.4 & 55.3 & \\
\hline
\end{tabular}

gas societies around the world, as shown in Table 4. From Table 4, the minimum and maximum values of ${ }^{40} \mathrm{~K}$ concentrations in this work are higher than those of Egypt, Turkey, Saudi Arabia, Sudan, Sri Lanka, and Kuwait and are lower than that of China. As for the minimum value of ${ }^{232} \mathrm{Th}$ concentrations, while this study is higher than those of Turkey, Sri Lanka, Norway, and Kuwait, it is lower than those of Egypt, Saudi Arabia, China, and Sudan. Also, the maximum value of ${ }^{232} \mathrm{Th}$ concentrations is higher than those of Egypt, Turkey, Saudi Arabia, Sri Lanka, Norway, and Kuwait, lower than those of China and Sudan. For the ${ }^{226} \mathrm{Ra}$ concentrations, the minimum level in the current study is higher than those of Egypt, Turkey, Sri Lanka, Norway, and Kuwait. It is lower than those of Saudi Arabia, China, and Sudan. The maximum limit of ${ }^{226} \mathrm{Ra}$ is higher than those of Egypt, Turkey, Sri Lanka, and Norway. It is less than those of Saudi Arabia, China, Sudan, and Kuwait.
Table 5 shows the results of the statistical analysis of the data of samples of oil and non-oil societies. The results of the Mann-Whitney test indicate that there are no statistically significant differences at the significance level $(p>0.05)$ between the samples of oil and non-oil societies about the TENORM ${ }^{40} \mathrm{~K},{ }^{232} \mathrm{Th}$, and ${ }^{238} \mathrm{U}$ concentrations. As for ${ }^{262} \mathrm{Ra}$ concentrations, the Mann- Whitney test results indicate that there are statistically significant differences at the significance level $(p>0.05)$ between samples of oil and non-oil societies in favor of samples taken from oil societies. Examining Figures 2, 3, 4, and 5 showed that concentrations of the TENORM, i.e., ${ }^{40} \mathrm{~K}$, ${ }^{232} \mathrm{Th}$, and ${ }^{238} \mathrm{U}$, vary from region to region. However, it is also noted that the distribution of radiations varies from region to region. The highest values are in the southeastern sites, and in these areas, most of the oil and gas production facilities are located, as well as the petroleum waste dump. 
Table 5. Descriptive statistics for sand samples.

\begin{tabular}{|cccccccccc||}
\hline \hline TEN & Type & Variance & Std. & Mev. & Min & Max & Skewness & Kurtosis & \multicolumn{2}{c|}{ Sigs. of Tests } \\
ORM & K. S. & M. W. \\
${ }^{40} \mathrm{~K}$ & SO & 2630.48 & 51.29 & 430.27 & 654.67 & $-1.04 \pm 0.50$ & $1.34 \pm 0.97$ & & \\
& SN & 2285.45 & 47.81 & 470.08 & 620.32 & $-0.71 \pm 0.60$ & $-0.40 \pm 1.15$ & 0.499 & 0.354 \\
& SO & 143.93 & 11.99 & 4.35 & 43.94 & $-0.13 \pm 1.15$ & $1.19 \pm 0.97$ & & \\
${ }^{232} \mathrm{Th}$ & SN & 67.31 & 8.20 & 6.37 & 34.64 & $0.64 \pm 0.60$ & $-0.18 \pm 1.15$ & 0.091 & 0.125 \\
& SO & 39.58 & 6.29 & 4.82 & 27.94 & $0.28 \pm 0.50$ & $-0.22 \pm 0.97$ & & \\
${ }^{226} \mathrm{Ra}$ & SN & 14.10 & 3.76 & 4.94 & 17.90 & $-0.24 \pm 0.60$ & $-0.62 \pm 1.15$ & 0.064 & 0.026 \\
& SO & 6.86 & 2.62 & 6.68 & 15.44 & $0.76 \pm 0.50$ & $-0.54 \pm 0.97$ & & \\
${ }^{238} \mathrm{U}$ & SN & 11.79 & 3.43 & 1.08 & 14.45 & $-0.36 \pm 0.60$ & $0.36 \pm 1.15$ & & 0.234 \\
\hline \hline
\end{tabular}

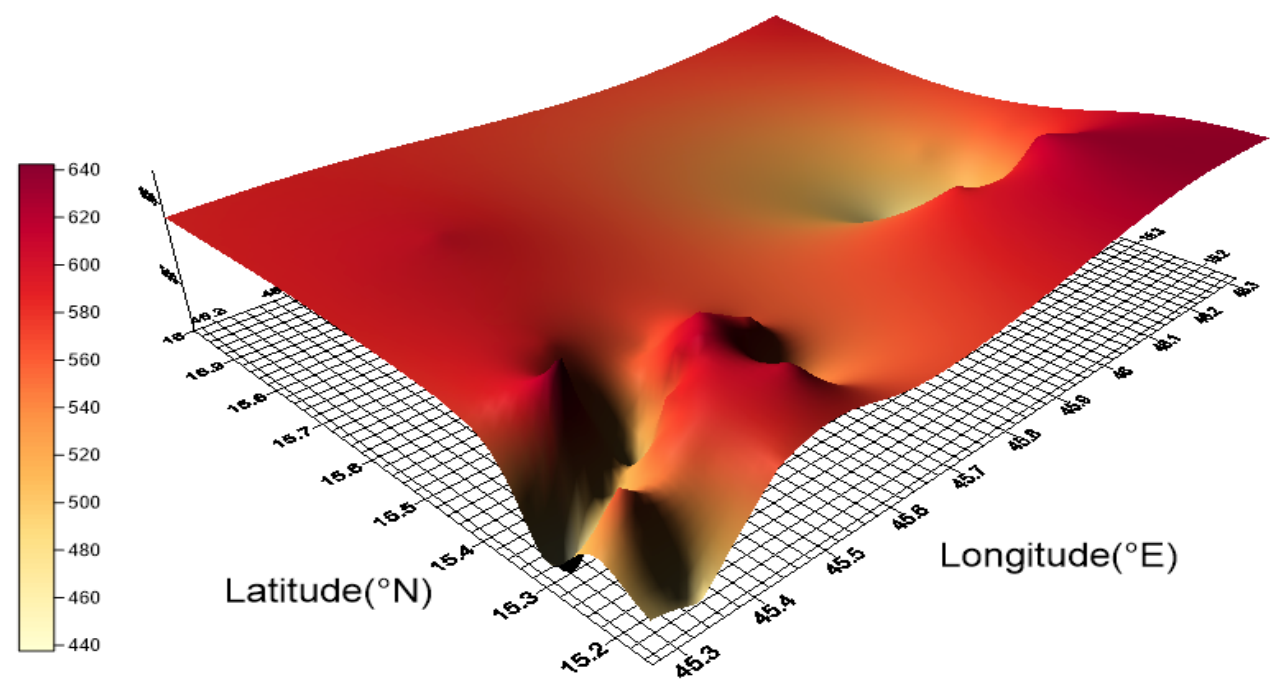

Fig. 2. Distribution Map of 40K (Bq Kg-1) in Sand Samples of Studied Area

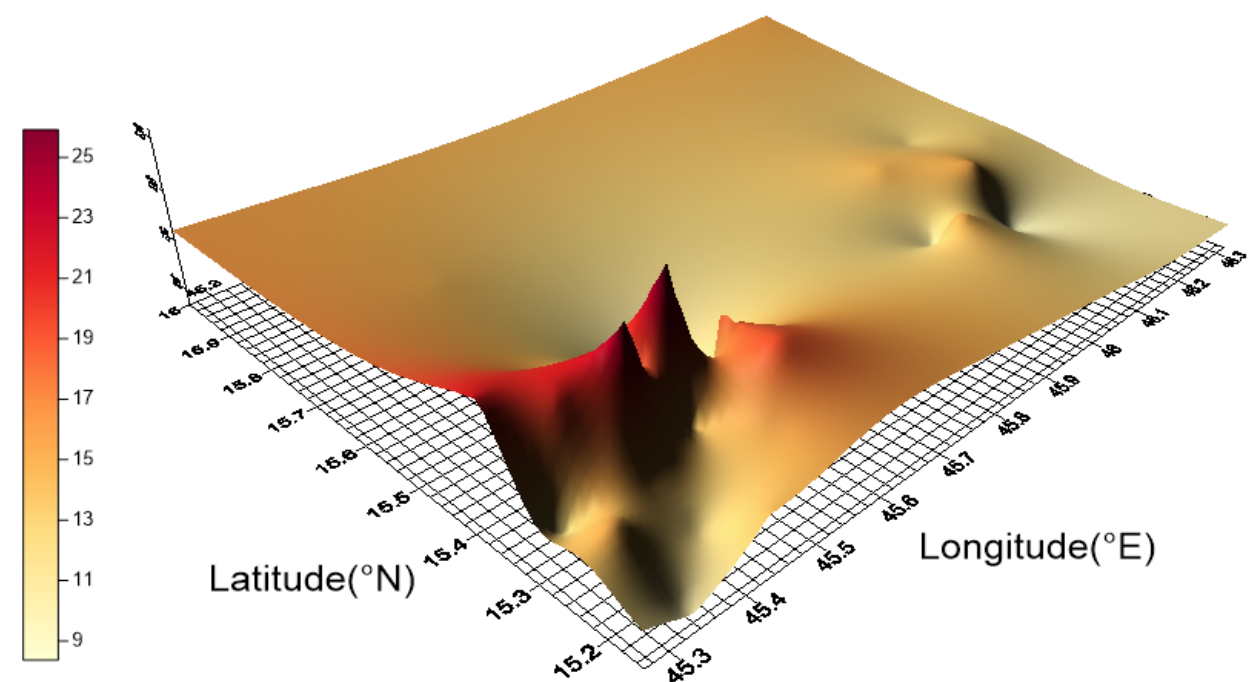

Fig. 3. Distribution Map of $232 \mathrm{Th}(\mathrm{Bq} \mathrm{Kg}-1)$ in Sand Samples of Studied Area 
These values decrease in the central, northern, and western locations. This may be attributed to the leakage of radionuclides resulting from the oil and gas industry and may be attributed to the geological structure of the area (Hassan et al., 2019; Yasmin et al., 2018; Karunakara et al., 2014). In general, there are no radiological hazards to the population or the environment. Nevertheless, the accumulation of these wastes over time may lead to future radiological problems. This study recommends that continuous monitoring and using safe and time may lead to future radiological problems. This study recommends continuous monitoring and using safe and modern methods and technologies to dispose of petroleum waste. This study provides basic information for assessing the potential effects of radiation doses and can be used as a baseline for future investigations.

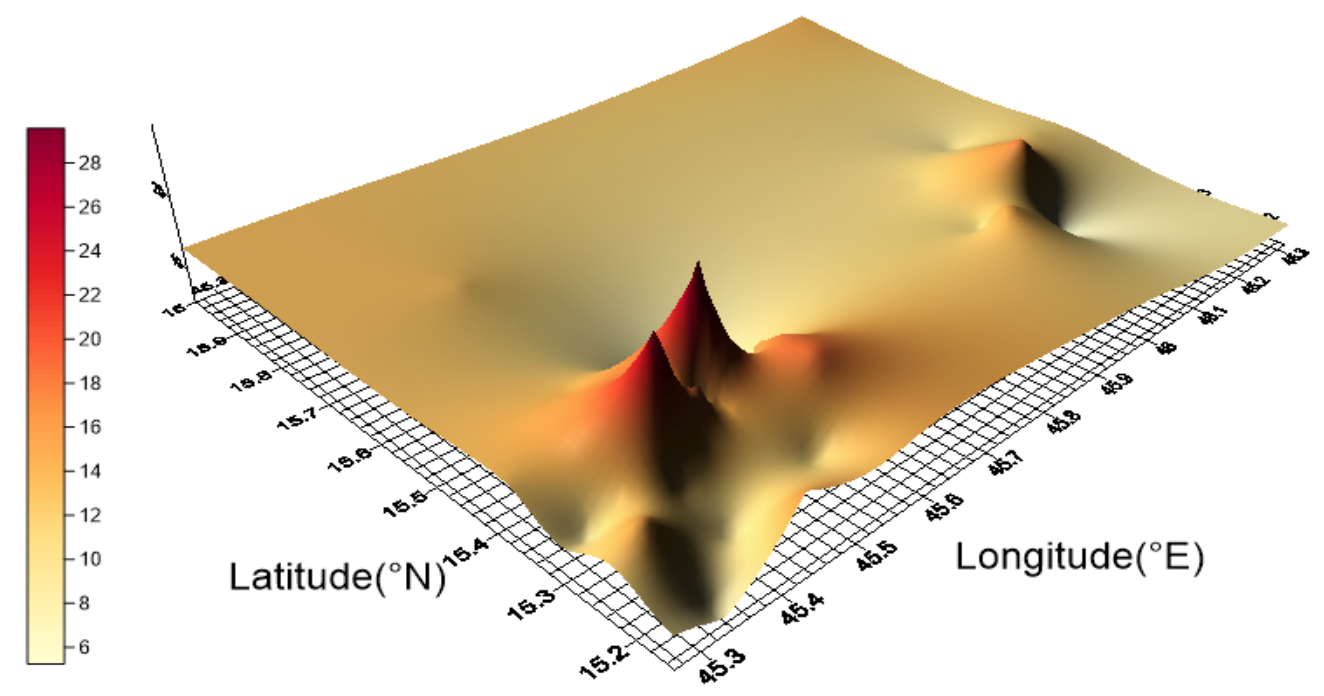

Fig. 4. Distribution Map of 226Ra (Bq Kg-1) in Sand Samples of Studied Are

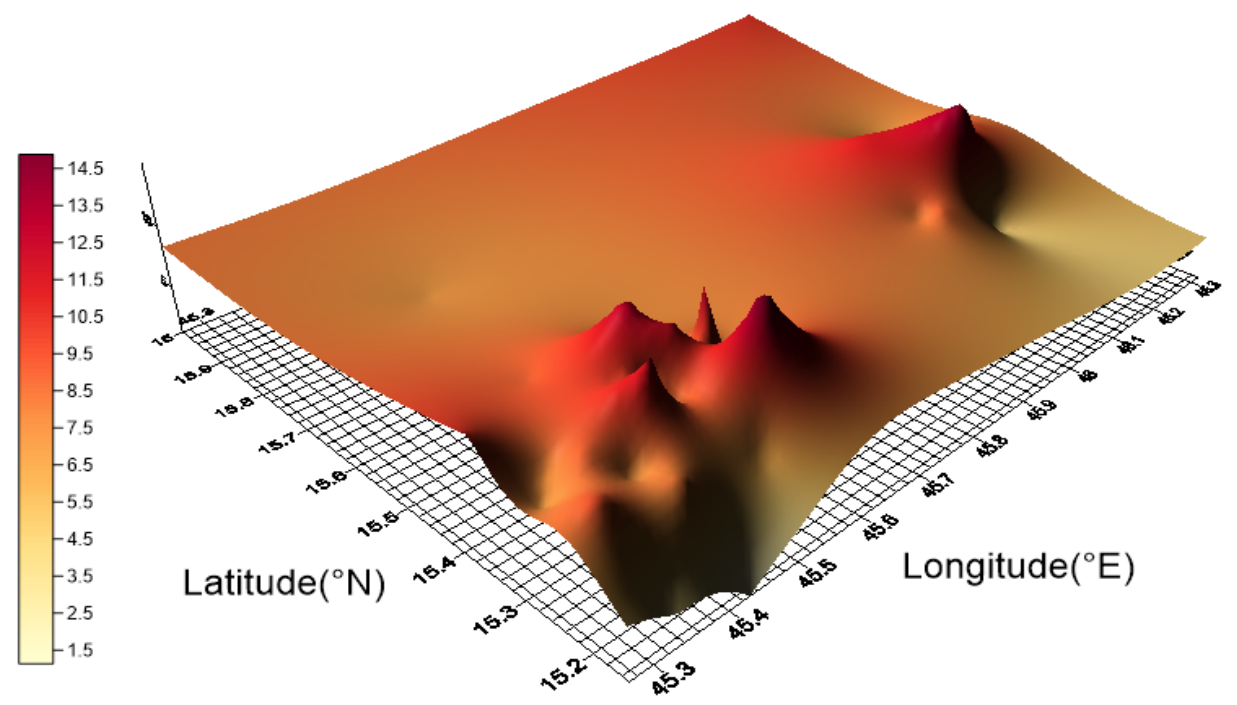

Fig. 5. Distribution Map of 238U (Bq Kg-1) in Sand Samples of Studied Area 


\section{Conclusion}

Such studies should be carried out for environmental monitoring of desert sands, especially those that are close to oil and gas industry facilities. In this work,35 desert sand samples were measured and analyzed for radioactivity due to ${ }^{40} \mathrm{~K},{ }^{232} \mathrm{Th},{ }^{226} \mathrm{Ra}$, and ${ }^{238} \mathrm{U}$ isotopes, where the concentrations of all radionuclides were less than the global average. The results did not show any radiological hazards currently to health or the environment. Contour maps indicate that the distribution of radioactivity varies from one region to another depending on the oil and gas industry facilities, where the accumulation of oil and gas waste for a long time may lead to possible radiological hazards in the future. Therefore, modern and safe methods should be used to dispose of petroleum waste.

\section{ACKNOWLEDGEMENTS}

Authors acknowledge support from the Institute of Technical Physics, Heilongjiang Academy of Sciences, College of Nuclear Science and Technology of Harbin Engineering University, and National Atomic Energy Commission of Yemen (NATEC).

\section{References}

Abu-Baker, A. O. K.; Elhassan, A.; Osman, A. H.; Elfaki, A. A. A. \& Elobaid, R. A. (2016). Measurement of Activity Concentration, Absorbed Dose Rate and Annual Effective Dose of Natural Occurring Radioactive Material (NORM) in Samples Encountered During Oil \& Gas Industry, IOSR J. Appl. Phys. , 8, 89 -95.

Alaamer, A. S. (2012). Measurement of Natural Radioactivity in Sand Samples Collected from Ad Dahna Desert in Saudi Arabia. World Journal of Nuclear Science and Technology 2, 187-191.
Ali, M. M. M.; Zhao, H., Li, Z. \& Ayoub, A. A. T. (2020). A review about radioactivity in TENORMs of produced water waste from petroleum industry and its environmental and health effects. IOP Conference Series: Earth and Environmental Science, 467, 012120 .

Ali, M. M. M.; Zhao, H.; Li, Z. \& Maglas, N. N. M. (2019). Concentrations of TENORMs in the petroleum industry and their environmental and health effects. RSC Advances, 9, 39201-39229.

Alkhayat, Z. Q. \& Almaliki, S. J. B. (2020). Effects of the deterioration of construction materials industry on the radioactivity background in Baghdad, Iraq. KUWAIT JOURNAL OF SCIENCE, 47, 97-102.

Alrefae, T.; Nageswaran, Tn.; AlFailakawi, A. \& Al-Shemaly, T. (2012). Radioactivity of long-lived gamma emitters in milk powder consumed in Kuwait and estimates of annual effective doses. Kuwait Journal of Science, 143-158.

Alrefae, T. \& Nageswaran, T. (2017). Detection of escape peaks in environmental gamma spectrometry. Kuwait Journal of Science, 44.

Alrefae, T.; Nageswaran, T. N.; Alshemaly, T. \& Demir, N. (2018a). Radiological assessment of flour consumed in Kuwait. Kuwait Journal of Science, 45.

Alrefae, T.; Nageswaran, T. N.; Demir, N. S.; Khandaker, M. U.; Bradley, D. A. et al. (2018b). Committed effective dose to the Kuwaiti population via the dietary intake of red meat. Results in Physics, 10, 827-831.

Argyrios, P.; Georgios, C.; Antonios, K. \& Stylianos, S. (2014). Natural radioactivity distribution and gamma radiation exposure of beach sands from Sithonia Peninsula. Open Geosciences, 6, 229-242. 
Attallah, F.A.; Hilal, M.A. \& Mohamed, Y.T. (2018). Preliminary investigations on reducing the high radiation risk level of TENORM scale waste from petroleum industry. Radiochimica Acta, 106, 793-800.

Baggoura, B.; Noureddine, A. \& Benkrid, M. (1998). Level of natural and artificial radioactivity in Algeria. Applied Radiation and Isotopes, 49, 867-873.

Bou-Rabee, F. (1997). Soil radioactivity atlas of Kuwait. Environment International, 23, 5-15.

Demir, N. S.; Nageswaran, T. \& Alrefae, T. (2018). Anti-Compton system for environmental radioactivity studies at Kuwait University. Kuwait Journal of Science, 45.

Ehsanpour, E.; Abdi, M. R.; Mostajaboddavati, M. \& Bagheri, H. (2014). ${ }^{226} \mathrm{Ra},{ }^{232} \mathrm{Th}$, and ${ }^{40} \mathrm{~K}$ contents in water samples in part of central deserts in Iran and their potential radiological risk to human population. Journal of Environmental Health Science and Engineering, 12, 80.

Fares, S. (2017). Measurements of natural radioactivity level in black sand and sediment samples of the Temsah Lake beach in Suez Canal region in Egypt. Journal of Radiation Research and Applied Sciences, 10, 194-203.

Fifield, F. W. \& Haines, P. J. (2000). Environmental Analytical Chemistry, Oxford, UK, Blackwell Science.

Gamage, S. S. N.; Ratnayake, R. M. T. S.; Senadhira, A. M. A. D. M.; Weerasinghe, D. A. \& Waduge, V. A. (2018). Radioactive and Non-Radioactive Element Analysis of Dorado Gas Discovery of Sri Lanka and Their Influence on Natural Environment, J. Trop. For. Environ, 8, 55-63.
Harrison, R. M. (1992). Understanding Our Environment and Pollution: Cambridge Royal Society, Cambridge, UK, Royal Society of Chemistry.

Hassan, N.; Mansou, N. A.; Salama, S. \& Seoud, M. S. (2019). Assessment of Radiological Hazards of Using Petroleum Raw Materials and their Waste. Radiat. Prot. Dosim, 185, 1 -13.

Hilal, M. A.; Abdelbary, H. M. \& Mohamed, G. G. (2018). Physicochemical and Radiation Hazardous Properties of Scale TENORM Waste: Evaluation by Different Analytical Techniques. Radiochemistry, 60, 444-449.

Jallad, K. N. (2013). Radioactive investigation of sand from the northern region of Kuwait. Environment and Natural Resources Research, 3, 68-77.

Karunakara, N.; Yashodhara, I.; Sudeep, K. K.; Tripathi, R. M.; Menon, S. N. et al. (2014). Assessment of ambient gamma dose rate around a prospective uranium mining area of South India - A comparative study of dose by direct methods and soil radioactivity measurements. Results in Physics, 4, 20-27.

Lavi, N.; Groppi, F. \& Alfassi, Z. B. (2004). The measurement of ${ }^{40} \mathrm{~K}$ in natural and synthetic materials by the method of high-resolution gamma-ray spectrometry. Radiation Measurements, 38, 139-143.

Majeed, H. N.; Ali, K. H. \& Hussein, J. H. (2014). Measurement Natural Radioactivity in Soil Samples from Important historical locals in Alnajaf Alashraf city, Iraq. Journal of Advances in Chemistry, 8, 1472 - 1478.

Manahan, S. (2017). Environmental Chemistry, Boca Raton: CRC Press. 
National Information Center, Y.-R. (2006). Administrative division of Ma'rib governorate for local administration (Fourth Conference of Local Councils - 2006). [Online]. Available: https://www.yemen-nic. info/gover/mareb/classoff/

Okeyode, I. \& Oluseye, A. (2010). Studies of the terrestrial outdoor gamma dose rate levels in Ogun-Osun river basins development authority headquarters, Abeokuta, Nigeria. Physics International, 1, 1-8.

Our Yemen Website Management. (2015). Comprehensive guide, your comprehensive guide to Yemen "all regions" [Online]. Available: http://www.yemenna.com.

Özmen, S. F.; Cesur, A., Boztosun, I. \& Yavuz, M. (2014). Distribution of natural and anthropogenic radionuclides in beach sand samples from Mediterranean Coast of Turkey. Radiation Physics and Chemistry, 103, 37-44.

Pillay, A. E.; Salih, F. M. \& Maleek, M. I. (2010). Radioactivity in oily sludge and produced waste water fromoil: environmental concerns and potential remedial measures. Sustainability, 2, 890-901.

Sparks, D. L. (2003). Environmental Soil Chemistry, Burlington, Academic Press.

Strand, T. (2004). NORM in the Norwegian Oil and Gas Industry - Activity Levels, Occupational Doses and Protective Measures The 11th IRPA International Congress..., ipen. br.

UNSCEAR. (2000). Sources and Effects of Ionizing Radiation. In: UNITED NATIONS SCIENTIFIC COMMITTEE ON THE EFFECT OF ATOMIC RADIATION, U. N., NY (ed.). New York.
Xinwei, L. \& Xiaolan, Z. (2006). Measurement of natural radioactivity in sand samples collected from the Baoji Weihe Sands Park, China. Environmental Geology, 50, 977-982.

Yasmin, S.; Barua, B. S.; Uddin, K. M.; Kamal, M.; Abdur, R. M. et al. (2018). The presence of radioactive materials in soil, sand, and sediment samples of Potenga sea beach area, Chittagong, Bangladesh: Geological characteristics and environmental implication. Results in Physics, 8, 12681274.

$\begin{array}{lr}\text { Submitted: } & 27 / 06 / 2020 \\ \text { Revised: } & 11 / 08 / 2020 \\ \text { Accepted: } & 12 / 08 / 2020 \\ \text { DOI: } & 10.48129 / \text { kjs.v48i3.10022 }\end{array}$

